\title{
From Conventional Recycling to Creative Reuse: Empowering Local Industrial Resources Through Synergistic Practices
}

\author{
AHMED K. ALI \\ Texas A\&M University
}

\author{
PATRICIA KIO \\ Texas A\&M University
}

\begin{abstract}
This paper seeks to introduce a novel approach in salvaging the urban realm through exploring ways in which design can extrapolate the use and the value of consistent industrial byproducts, mainly from the automobile industry. The research begins with a need to conserve materials and energy with a focus on adding value by design. In this paper, a speculative design work and comparative analysis have been conducted. The method begins with the analysis of automobile byproduct materials, observations of procurement of new material and analysis of proposed designs of automobile body manufacturing. The goal of the study is to transform the linear approach in making building components, in particular, building exterior metal skins and cladding systems, to a closed-loop approach, which ensures multi-dimensional economic, social, and environmental benefits. The study introduces a novel approach in initiating a symbiosis between non-hazardous automobile waste and the building and construction industry. In particular, creating building skin systems from by-product galvanized sheet metal from the automobile industry. The results are expected to change the focus of the current waste management practices in the manufacturing industry from conventional recycling to creative reuse.
\end{abstract}

\section{INTRODUCTION}

In the United States, more than 7.6 billion tons of non-hazardous waste is generated annually. Metal scrap is generated from many industries, but perhaps the most significant source of metal scraps comes from the automobile industry. Empirical evidence suggests that there are significant economic, environmental, and social benefits of reusing industrial waste than recycling it. Emerging ecosystem concepts such as cradle-to-cradle, design for disassembly, sustainable manufacturing, and recently, circular economy promote the concept of reuse over recycling. Sheet metal has been used for building facades since the nineteenth century. The use of sheet metal for architectural purposes was comparatively new in the 1870 s, but in the preceding several decades, it became a primary building material that helped to change the language of architecture all across the United States. ${ }^{1}$ Sheet metal was mainly used for building exteriors, and therefore protection from corrosion became a priority. A hot-dipped galvanization process was introduced to the market which, made iron more suitable for exterior work. ${ }^{1}$ Sheet metal grew in acceptance and was in demand at the beginning of the 19th century. The chief selling point for all the architectural sheet metal products was that they presented an economical means of ornamentation. Literature suggests that nearly $30 \%$ of all energy consumed in the world comes from the buildings industry. Increased reuse of industrial waste materials over recycling it is expected to reduce the energy consumed in extraction and manufacturing and thereby reduce the carbon footprint of buildings. The speculative design presented in this paper demonstrates how by-products of galvanized sheet metal from the automobile industry could be transformed to building facade systems. The methodology includes geometric analysis, application of design principles, and the establishment of energy values of embodied energy.

Studies suggest that material and energy transfers between industries and/or companies create interactions and structures analogous to predator-prey species interactions in an ecological food web. An Ecological Network Analysis (ENA) can inform a sustainable organization of material and energy flows among industries that were not previously in the network design space. Expanding the number of design solutions for sustainable networks is especially important in today's world, where resources that have historically been readily available are becoming scarce, and climate changes are requiring a rapid reduction in emissions. ${ }^{2} \mathrm{~A}$ symbiosis between the automobile industry and the building industry can be established through design solutions with a focus on sustainability. Industrial symbioses, also known as ecoindustrial parks (EIP), occur when multiple firms or facilities in a bounded geographic area achieve higher system efficiency through the exchange of "waste" energy and materials. ${ }^{3}$ This newly found adroitness of designing with industrial solid waste seeks to apply circularity of materials primarily in the revival of American industrial cities such as Detroit. In this study, the building skin is reintroduced as a positive development to cost and energy. The study attempts to develop answers to the following inquiries: (1)What is the role of architecture in salvaging and invigorating the urban realm (the industrial city/Detroit as an example?, (2) How can we empower local resources by creating synergistic channels between industrial automobile by-products and the building industry products? (3) How do we seek to deploy a newly found adroitness to address the paradigm shift of the resource reuse revolution? (4) How to address the economy of means and the need for new identities? (Circular Economy/ transfer of knowledge between the automobile and the building industries?) 
ON SALVAGING AND INVIGORATING THE URBAN REALM "The lack of real estate in some cases and bustling economies in others, have increased the need of repurposing what already exists, reinforcing strategies of adaptability, transformation and reuse, therefore raising awareness of the behavior and evolution of architecture over time."

\section{-Nascent Material Conscience, ACSA session call}

The inhabitants of the urban space shape the urban realm. Occupants shape the urban realm by their characters and the economic opportunities that exist. Jane Jacobs in her book, The Death, and Life of Great American Cities stated that invigorating the urban space began by combining known ideas from different fields of economic activity or applying some ideas from one field into another. This is a fundamental concept in salvaging the urban realm and is demonstrated by the work in this study. It may seem obvious today but was probably less so in 1969 when "The Economy of Cities" was published. ${ }^{4}$ Cities today must take advantage of the shrinking urbanism by focusing on the individual city's resources and characteristics, aiming to eventually return to a growth path or stop the declining process. ${ }^{5}$ The call to focus on the city's resources is an excellent basis to harness the non-hazardous solid waste of the automobile industry especially in those industrial cities that flourished on car manufacturing.

The problems of Detroit's urban realm began with the reduction in sales in the automobile industry. ${ }^{7}$ This led to a catastrophic reduction in employment, and therefore a shrinking population. According to several studies based on the political economy, the urban decline is an outcome of market forces and therefore an affected city would shrink until it reaches a new equilibrium of supply and demand but driven by market interests and neoliberal policies, aiming to grow. ${ }^{8-10} \mathrm{~A}$ closer look at the city of Detroit reveals a surprising pattern: a downtown area with healthy numbers of employees and employers surrounded by a ring of vacant neighborhoods. Most of the neighborhoods have been abandoned or demolished over the years, and in some of these areas, the city has stopped providing services. ${ }^{7}$ Figure 1 shows a significant rising trend in vacant lots, unoccupied, occupied, and unknown areas from 2006 till 2015 before a return to pre-2011 trend. The different paradigm shifts of transportation, raw materials and population shrinkage call for new solutions.

Spatial transformations occurred as factories spread out into the suburbs making neighborhoods vacant as plants changed ownership and locations. The factories continue to thrive as the demand for automobiles increases in the US. The thriving factories provide local resources through their industrial byproducts which can then be used as the basis to build nothing but to transform everything. Detroit has a problem that is paradoxical. There is a housing crisis in some areas as other areas are gentrified. The role of architecture, in this case, is initiated

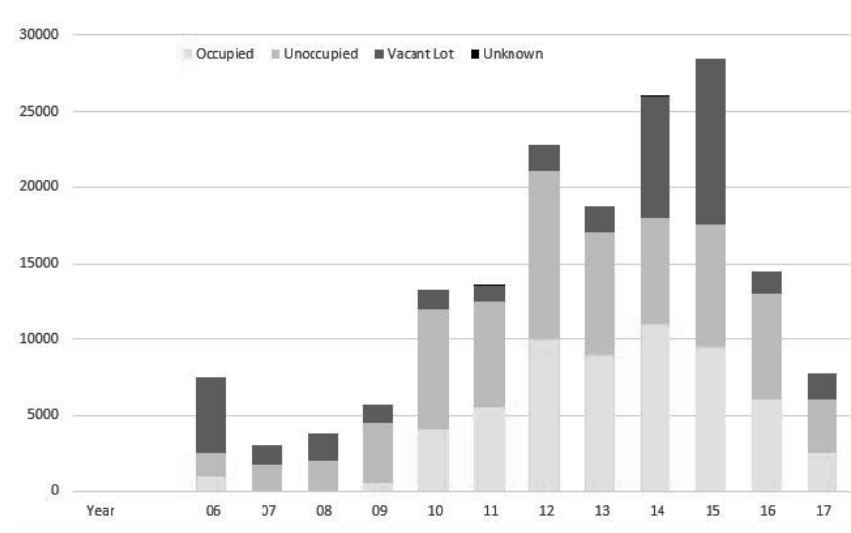

Figure 1: Detroit properties up for auctions. Source: Authors reproduced of Wayne County Treasurer via Loveland Technologies.

through a resource-based design which culminates in a practical and economical solution for the Detroit urban area. ${ }^{11}$

\section{EMPOWERING LOCAL RESOURCES THROUGH SYNERGISTIC PRACTICE}

The state of Michigan has remained the highest producer of automobiles accounting for over $30 \%$ of the assembly of passenger vehicles in the United States since $1957 .{ }^{12}$ Although automobile factories in and around Detroit which received a bailout from the federal government in 2009 are still thriving, the city filed for bankruptcy in 2013. ${ }^{13}$ There is a widening gap between the city's urban regeneration and the auto industries. However, beyond that, the ties between the two are weakening. A material flow mechanism between the automobile and the building industry could be established to lower the cost of building exteriors. Improving the value of the use of local resources will be good for the supply chain and potentially building skin designs can be added to the exciting yearly auto show. A fundamental shift is required in the procurement of raw materials within the construction industry to preserve the environment and reduce the pace of climate change. This study proposes a way to use galvanized sheet metal scrap from the automobile industry processes for building skins. According to a recent report published by the Grand View Research Group, the world's most extensive and most trusted market research database, the market size of global metal stamping (a manufacturing term for forming sheet metal) was estimated at 204.6 billion dollars in 2016 and is expected to reach 299.6 billion dollars by $2025 .{ }^{14}$ The process of building the headquarter office building for the Aluminum Company of America (Alcoa) at Pittsburg, Pennsylvania, is an example of knowledge transfer of metal stamping processes between the automobile and the building industries. ${ }^{15}$

\section{THE ALUMINUM COMPANY OF AMERICA BUILDING (ALCOA): A CASE STUDY}

The Alcoa Building in Pittsburg was constructed in 1953. In the design and construction process, an interdisciplinary approach is evident from its conception to its realization. It 
is pertinent to note that in the construction of the building façade system was possible by applying the knowledge and the technology of the Pullman Standard Car Manufacturing Company in Hammond, Indiana. Pullman experimented with modified stamping processes, and preliminary production runs were made. Dozens of designs for the curtain wall panels were submitted until a $6^{\prime} \times 12^{\prime}$ aluminum panel, stamped from a 1/8-inch aluminum sheet, was selected and placed in production. The building skin was conceived as weathertight curtain walls that increased usable office spaces while retaining their ability to withstand high wind loads. There were $30-50 \%$ savings in structural framework required for traditional masonry building. There was no taping or calking of joints which also reduced costs. Another important fact was that the time for installation was faster than masonry construction due to the large size of panels. In this scenario, we see new ways of combining materials, methods, and technologies. Figure 2 shows the stamped aluminum panels prototype.

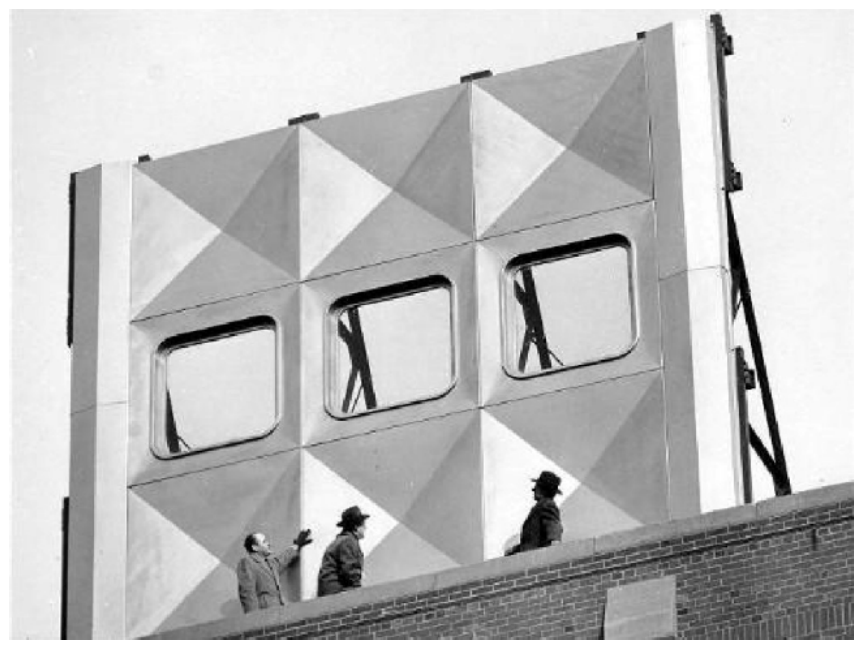

Figure 2: The Alcoa Stamped Aluminum building façade prototype. Source: Alcoa.

\section{ISSUES OF SCRAP METAL AND DE-GALVANIZATION}

The recent trade conflict between the U.S. government and other nations that started when the Trump administration imposed tariffs on imported steel and aluminum is causing a great deal of concern. Aside from the politics regarding steel and aluminum imports, to justify reusing galvanized sheet metal over de-galvanizing and to recycle it, one must understand first the recycling process within the scope of energy consumption. Scrap drives were first embarked on during the war days. Packard Motor Car Company started the first scrapcollection drive program among its dealers. General Motors followed a month later with a campaign. ${ }^{18}$ The technical and economic feasibility of available de-zincing technologies pales in comparison to the practicality of material reuse. The cost of de-galvanizing steel is overwhelmingly high. This study focuses on the size-predicted scrap accrued during the production of stamped sheet metal in making the automobile body parts.
The auto industry generates a uniformed high-quality scrap, which makes it a favorite to the many steel mills that purchased this material for recycling. ${ }^{19}$ Hot-Dipped galvanized sheet metal used in the automobile body is typically a carbon steel sheet coated with zinc on two sides by the continuous hot-dip process. The process results in a layer of zinc on each side of the steel sheet that is tightly adhering to the steel through the formation of an iron-zinc alloy bonding layer that is formed by a diffusion process while the heated steel strip is in contact with the molten zinc. Reusing of this material is predicted to reduce the energy used in de-zincing during recycling. Galvanized sheet metal requires no maintenance during the first 60-year life due to its durability, resilience, and availability; the scrap metal can be reused for building purposes.

\section{COMPARISON BETWEEN A PROPOSED METAL SKIN DESIGN AND THE ALCOA CURTAIN WALL}

In this study, the Resource-Based Design Research Laboratory team (RBDR) focused on the reuse of predicted galvanized sheet metal scraps from the automobile industry known as offal, in the design of exterior building skins. Offal is cut-outs from galvanized sheet metal used in the body of vehicles. A Life Cycle Assessment (LCA) was conducted based on material use from cradle to cradle. The assessment focused on the material and energy savings in the design and production phases. A preliminary Life Cycle Cost assessment (LCC) is traced for material procurement and transportation. Embodied energy and carbon emissions are two relevant metrics were used in assessing the building skin. In this study, extraction of raw material begins with the choice to reuse material for building skins. The structural support systems for the skins are not included in this study.

Embodied energy includes all the energy required to manufacture and transport building materials, and also to construct, maintain, and demolish a building. Literature suggests that the input-output hybrid method is considered the most reliable for the calculation of embodied energy. ${ }^{20}$ It is calculated from methods of production, installation, use, and demolition. It gives more details in order to make a holistic choice of materials with parameters involved on a case by case basis. The product stage in a material's life cycle which comprises raw material supply, transport and manufacturing tend to be the stage with the highest impact on the lifespan of a building. ${ }^{21}$ The construction process stage includes the transport and installation process. ${ }^{21,22}$ Transportation of materials increases energy consumption and other environmental impacts. ${ }^{23}$ Accounting for carbon footprints is a question of quantifying and presenting emissions data for the whole life cycle of products in a consistent manner. ${ }^{24}$ The embodied energy coefficient of aluminum is $217 \mathrm{MJ} / \mathrm{kg}$ and galvanized steel is $39 \mathrm{MJ} / \mathrm{kg}$, the embodied carbon is $11.5 \mathrm{kgCO} 2 / \mathrm{kg}$ for aluminum and galvanized steel is $2.82 \mathrm{kgCO} 2 / \mathrm{kg} .{ }^{25}$ The Alcoa aluminum panel system is compared to a metal façade system developed by the RBDR team. The production of Alcoa 
panels involved stamping at Hammond Indiana and electrochemical finish at Stolle Corporation in Sidney, Ohio. From Ohio, they were shipped to a Pittsburgh warehouse.

\section{A PROPOSED FLAT METAL PANELS CLADDING SYSTEM} The transformation strategy of this design proposal involved maximizing the use of offal while minimizing both fabrication processes and additional waste. The design utilized all the eleven shapes and sizes of GM offal produced by the Lansing stamping plant to create an exterior cladding system without generating any additional waste (figure 3 ). The design is based on designing a standardized unit of panel size that corresponds to the scale of a typical 8" CMU block and fits within the edges of the offal's irregular shapes. A total of 32 square units measured $\left(8^{\prime \prime} \times 8^{\prime \prime}\right)$ generated from all eleven different offal units are composed as follows: five offal types with two units, four with three units, one with four units, and one with six units. Each offal piece was folded at 90-degrees on each side of the square unit, folded toward the same direction to create one flat, rectangular surface, with one side with the revealed wings formed from the folds. The wings can then come together between the offal units to create a clean, precise edge that is riveted together, ideally with a thermal break separating the inside from the outside. There are numerous configurations for arranging the paneling system based on a simple orthogonal grid. Two different-sized compositions were developed that have one of each of the eleven offal units. Shorter panels consist of the offal arranged in a seemingly geometrical pattern sized eight units high and four units wide $\left(2^{\prime}-8^{\prime \prime} \times 5^{\prime}-4^{\prime \prime}\right)$. The other panel is 16 units high and two units wide (1'-4" $\left.\times 10^{\prime}-8^{\prime \prime}\right)$ (figure 3 ). Simple manufacturing processes, as described above, transformed the irregular, undefined shapes of offal into a simple metal panel cladding system. Performing Computer Numerically Controlled cuts (CNC) using a waterjet machine, and simple right-angle folding using a magnetic brake, on the flat panel to make them perforated further expanded its uses and applications. This design calls for optimizing the application of the skin on the building by minimizing the manipulation of the individual offal units and creating the simplest yet efficient building skin. The size of the offal, determined by the number of units within each shape, imposes regularity on the various, irregular shapes. Rigid insulation could be applied to the inside of the panels to minimize heat transfer similar to Structural Insulated Panels systems (SIPs). The offal pieces come together to make larger composite panels that are easy to construct, install, and make use of all the different offal shapes. The electro-galvanized coating process makes sheet metal semi-ready for exterior applications and weathering. Formation of the galvanized sheet metal simply by bending, folding, punching, and cutting, does not sacrifice its resistance to corrosion due to the thickness of the zinc coating. However, a corrosion-resistant coat and finish paint are still required to protect the exposed sides from cutting and punching. According to the literature, hot-dipped, galvanized zinc coating, which is another process used by GM to protect sheet metal, can be up to 60 microns and last for approximately 60 years. ${ }^{26}$ To equate the area of an Alcoa panel to the flat metal panel system made up of eleven offal, the subsequent quantification was conducted:

- The area of one Alcoa panel is $6^{\prime} \times 12^{\prime}=72$ square feet or 10,368 square inches

- Area of one flat metal panel system = 32" x 64" = 2084 square inches or 14.47 square feet

- Therefore $72 / 14.47=4.97$ units

- Approximately five panels of offal panel = 1 Alcoa panel

- The total area of eleven offal is $27049.9 \mathrm{~cm} 2$. To find mass, we calculate for zinc and steel.

- Coating Thickness of zinc for $60 \mathrm{G} 60 \mathrm{G}$ is $140 \mathrm{~g} / \mathrm{m} 2$ and $160 \mathrm{~g} / \mathrm{m} 2$ [27]

- Offal 2 mass of zinc with coating of EG70G70G $=0.0160$ x $3014.1=48.2 \mathrm{~g}$

- Area of ten offal with coating of EG60G60G is 27049.9$3014.1=24035.8 \mathrm{~cm} 2$

- The density of zinc is $7.134 \mathrm{~g} / \mathrm{cm} 3$

- Mass of zinc $=0.0140 \times 27329.8=382.6 \mathrm{~g}$

- Total mass of zinc $=382.6+48.2=430.8 \mathrm{~g}$

- Calculating for total volume of offal $=1924.54 \mathrm{~cm} 3$

- Total mass $=$ total volume $x$ density $=1924.54 \times 7.134=$ $13730 \mathrm{~g}$ or $30.3 \mathrm{lb}$

- Total mass of steel $=$ Total mass - total mass of zinc $=$ $13730-430.8=13,299.2 \mathrm{~g}$ or $29.3 \mathrm{lb}$

- $\quad$ Five groups of flat metal panel systems $=13299.2 \times 5=$ $66496 \mathrm{~g}$ or $146.6 \mathrm{lb}$

The cost of metal in Michigan for new and scrap metals were compared. For new materials, the cost was obtained from a local supplier [28]. Galvanized sheet metal costs $\$ 10.48$ for a 3' $\times 2 \frac{1}{4}$ " sheet. Twelve sheets make an Alcoa panel giving a total cost of $\$ 125.76$. Aluminum sheet costs $\$ 46.21$ for a $4^{\prime} \times 24^{\prime \prime}$ sheet. Nine sheets make one Alcoa panel giving a total cost of $\$ 415.89$. For scraps, the prices in Michigan are $\$ 0.53 / \mathrm{lb}$. For aluminum sheet and $\$ 0.08 / \mathrm{lb}$. For galvanized sheet metal. ${ }^{29}$

\section{CONCLUSION}

An input-output hybrid has been used to carry out a quantitative assessment of the production of metals. The numbers of units used for galvanized sheet metal are much more than the Alcoa panel, but the mass of both are close at $66.5 \mathrm{~kg}$ and $57.3 \mathrm{~kg}$ respectively when the thicknesses have a considerable difference. The thickness of the aluminum panel is $3.175 \mathrm{~mm}$, and the thickness of the flat metal panel system has a range of $0.7 \mathrm{~mm}$ to $0.75 \mathrm{~mm}$. Coefficients for reuse of materials will improve the study of reuse. In figure 4 the embodied energy, carbon emission, distance, cost of new materials indicates enormous gains 


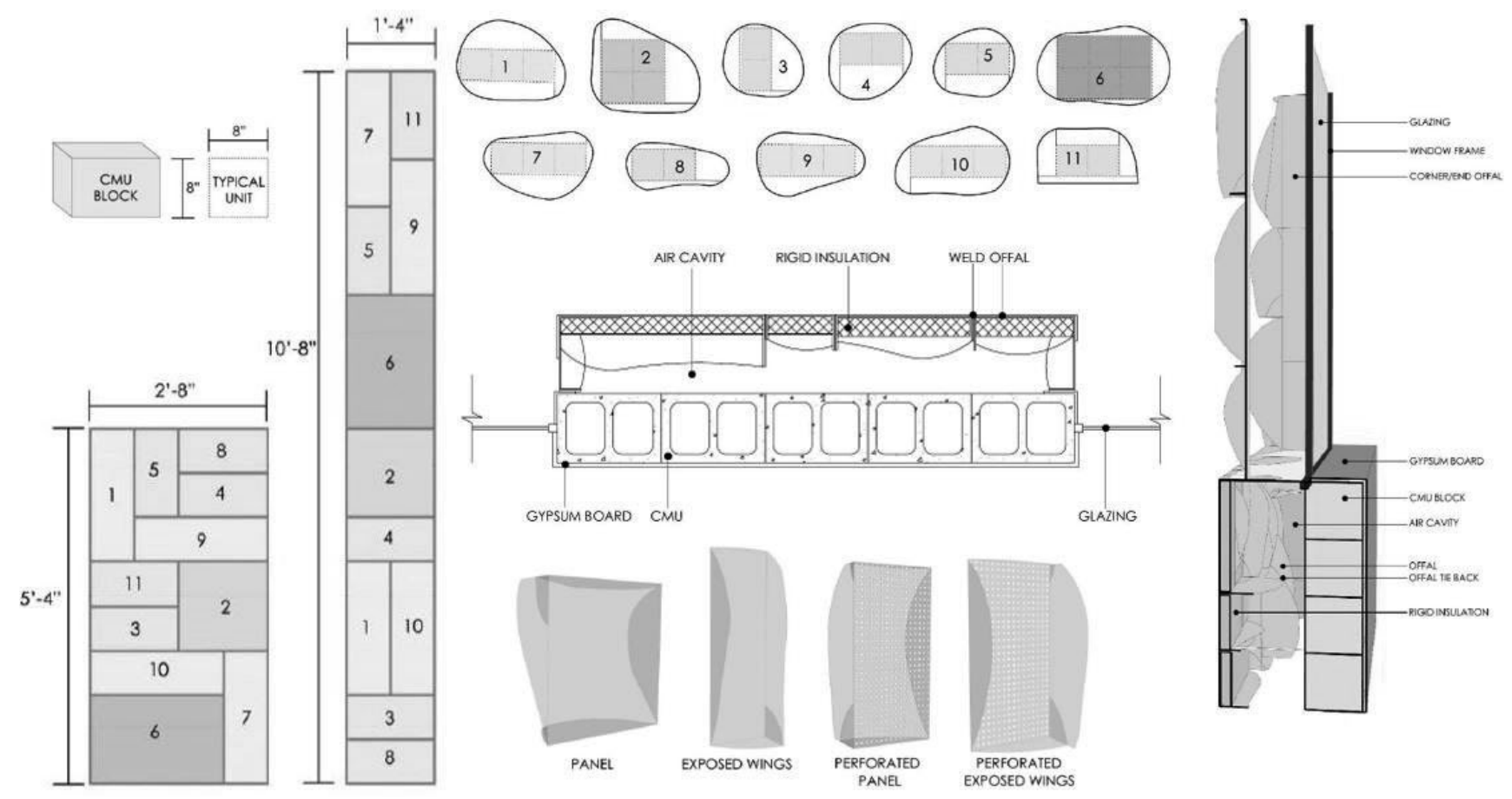

Figure 3: Flat Metal Panels Cladding System as a Building Skin. Source: Saqib, 2016

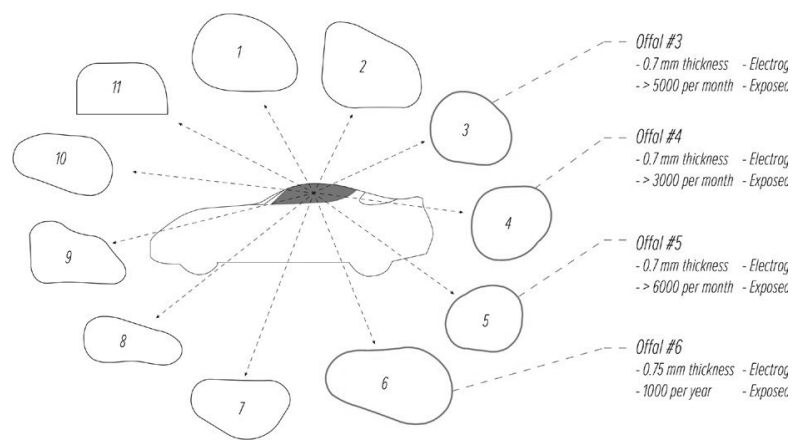

Figure 4: Offal from Blanking Process. Source: Mangers, 2016

$\begin{array}{lll}\begin{array}{l}\text { Inventory of energy } \\ \text { consumption }\end{array} & \begin{array}{l}\text { Alcoa Aluminum Panels } \\ \text { System }\end{array} & \begin{array}{l}\text { Flat Metal Panel Cladding } \\ \text { System }\end{array} \\ \text { Material } & \begin{array}{l}\text { Aluminum } \\ \text { Stamping \& bolting }\end{array} & \begin{array}{l}\text { HDG ECG Steel } \\ \text { bending \& bolting }\end{array} \\ \text { Production } & 1 & 5 \\ \text { No of units } & 126.41 \mathrm{~b} / 57.3 \mathrm{~kg} & 146.61 \mathrm{~b} / 66.5 \mathrm{~kg} \\ \text { Mass of material } & 3.175 & 0.75 \& 0.70 \\ \text { Thickness }(\mathrm{mm}) & 500 \text { miles } & 139 \mathrm{miles} \\ \text { Transportation Distance } & 500 \times 513.5=256.7 & 139 \times 513.5=71.4 \\ \text { Truck Carbon Emission }(\mathrm{kg}) & 56.5 \times 39=2593.5 \\ \text { Embodied Energy for virgin } & 57.3 \times 217=12,434.1 & 66.5 \\ \text { material }(\mathrm{MJ}) & & 66.5 \times 2.82=187.53 \\ \text { Material carbon } & 57.3 \times 11.5=659 & 125.76 \\ \text { emission }\left(\mathrm{kgCO}_{2}\right) & & 0.08 \times 146.6=11.73 \\ \text { Cost of new material }(\$) & 415.89 & \\ \text { Cost of scrap (\$) } & 0.53 \times 126.4=67 & \end{array}$

Table 1: Comparison of Alcoa Panels and FMP Cladding Systems Source: Authors, 2018
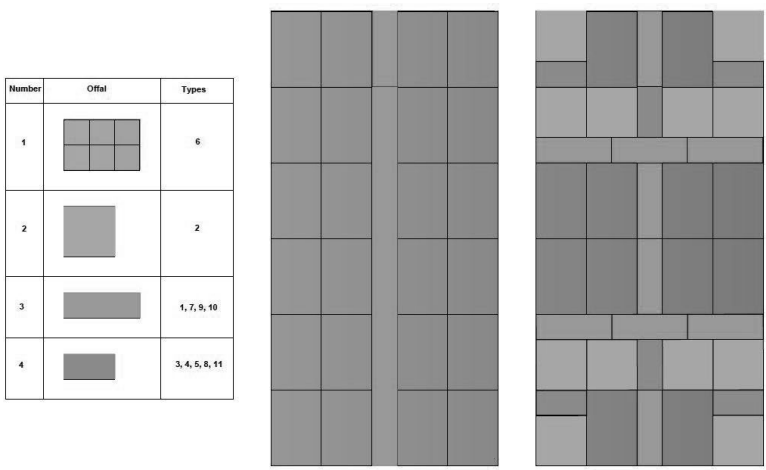

Figure 5: A 6’X12' Galvanized Skin Panels. Source: Authors, 2018

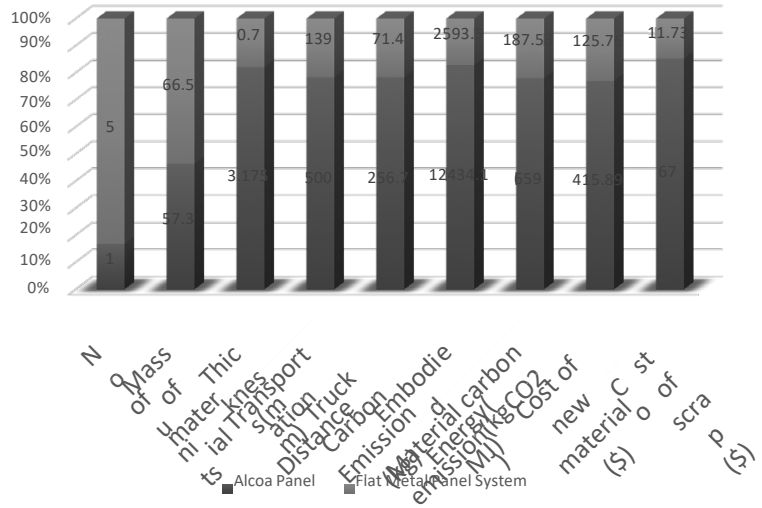

Figure 6: Comparison between parameters. Source: Authors, 2018 
where the flat metal panel system has an advantage of over five times when compared to the aluminum panel used for the Alcoa panel. The cost of aluminum scrap is about six times the cost of steel scrap showing economic gains. Architecture, therefore, plays a critical role in salvaging and invigorating the urban realm. The study argues that a resource revolution is making way for a new architectural paradigm shift, which is emerging through the integration of creative reuse, synergistic business processes, and circular economy.

\section{ENDNOTES}

1. Simpson, P.H., "ORNAMENTAL SHEET METAL IN THE UNITED STATES, 1870-1930." Journal of Architectural and Planning Research, 1994. 11(4): p. 294-310.

2. Layton, A., B. Bras, and M. Weissburg, "Designing Industrial Networks Using Ecological Food Web Metrics." Environmental Science \& Technology, 2016. 50(20): p. 11243-11252

3. Reap, J. and B. Bras, "A Method of Finding Biologically Inspired Guidelines for Environmentally Benign Design and Manufacturing." Journal of Mechanical Design, 2014. 136(11): p. 111110-111110-11.

4. Duranton, G., "The death and life of great American cities / The economy of cities." Regional Studies, 2017. 51(12): p. 1871-1873.

5. Owzar, A. and A.B. Lampen, Schrumpfende Städte: ein Phänomen zwischen Antike und Moderne. 2008.

6. Doucet, B., Why Detroit Matters: Decline, Renewal, and Hope in a Divided City. 2017, Bristol, UK: Policy Press.

7. Owens lii, R., E. Rossi-Hansberg, and P.-D. Sarte, Rethinking Detroit. Working Papers Series (Federal Reserve Bank of Richmond), 2017. 17(4): p. 1-45

8. Glaeser, E.L., "Are cities dying?" Journal of Economic Perspectives, 1998. 12(2): p. $139-160$.

9. Glaeser, E.L. and J. Gyourko, "Urban decline and durable housing." Journal of Political Economy, 2005. 113(2): p. 345-375.

10. Hackworth, J., "The Normalization of Market Fundamentalism in Detroit: The Case of Land Abandonment 1," in Reinventing Detroit. 2017,
Routledge. p. 75-90.

11. Ali, A.K., "Architecture within a circular economy: Process mapping resource-based design-bid-build project delivery system." Enquiry, 2017. 14(1): p. 48

12. Association, A.M., 1970 Automobile Facts, and Figures. Automobile Manufacturers Association, Inc., 320 New Center Building, Detroit, Michigan 48202. 70p. Free. Travel research bulletin, 1972. 10(3): p. 10-11.

13. Plumer, B., "We saved the automakers. How come that didn't save Detroit?," in The Washington Post. 2013: USA.

14. Grand View Research, I. Metal Stamping Market Analysis By Process (Blanking, Embossing, Bending, Coining, Flanging), By Application And Segment .

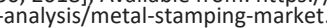

15. ALCOA, Aluminum on the Skyline. 1953.

16. Bouchet, M. and J. Parilla, How Trump's steel and aluminum tariffs could affect state economies. 2018, Brookings: Washington DC.

17. Gorrell, M., "Trump's proposed tariffs on steel and aluminum could slow Utah's growth, critics say," in The Salt Lake Tribune. 2018: Utah.

18. "INDUSTRY HUNTS SCRAP." BusinessWeek, 1948(961): p. 20-20.

19. Lawrence, J., "The scrap cycle completes round trip for automaking." American Metal Market, 2016: p. 30.

20. Dixit, M.K., C.H. Culp, and J.L. Fernandez-Solis, "Embodied Energy of Construction Materials: Integrating Human and Capital Energy into an 2 (3): p. 1936-1945.

21. Pomponi, F., A. Moncaster, and C. De Wolf, "Furthering embodied carbon assessment in practice: Results of an industry-academia collaborative research project." Energy and Buildings, 2018. 167: p. 177-186.

22. Rasmussen, F.N., et al., "Analysing methodological choices in calculations of embodied energy and GHG emissions from buildings." Energy and Buildings,
23. Chowdhury, R., D. Apul, and T. Fry, "A life cycle based environmental impacts assessment of construction materials used in road construction." Resources, Conservation and Recycling, 2010. 54(4): p. 250-255

24. Weidema, B.P., et al., Carbon Footprint: A Catalyst for Life Cycle Assessment? 2008, MIT PRESS: United States. p. 3.

25. Hammond, G. and C. Jones, Inventory of carbon \& energy: ICE. Vol. 5. 2008 Sustainable Energy Research Team, Department of Mechanical Engineering University of Bath.

26. WOOLLEY, T., Galvanizing and sustainable construction: A specifiers' guide. 2008, European General Galvanizers Association: United Kingdom.

27. Dallin, G.W. and G.C. Director, Galvanizing-2012. Continuous hot-dip galvanizing-process and products. Galvinfo Center-A program of the international zinc association. URL (available at http://www. galvinfo. com/ GalvInfo_2012_Course_Docs/Galvanizing\% 2020120831. pdf), 2012.

28. Lowe's. Imperial 24-in x 3-ft Galvanized Steel Sheet Metal. 2018 [cited 2018 Aug 8, 2018]; Available from: https://www.lowes.com/pd/ IMPERIAL-24-in-x-3-ft-Galvanized-Steel-Sheet-Metal/3234805.

29. Services, I.M.S.M. Scrap Metal Prices. 2018 June 20, 2018; Available from http://www.877ironmike.com/metal-prices. 